\title{
Water interaction with dental luting cements by means of sorption and solubility
}

Interação da água com cimentos dentais de acordo com a sorção e solubilidade

Larissa Pinceli CHAVES

DDS - MS - Dentistry Department - Division of Dental Materials Paranaense University UNIPAR - Cascavel - PR - Brazil

Fabiana Mezzaroba Ortenzi GRACIANO DDS - MS - Department of Operative Dentistry - University North of Paraná UNOPAR - Londrina - PR - Brazil

Odair BIM JÚNIOR

DDS -Department of Operative Dentistry - Endodontics and Dental Materials - Bauru School of Dentistry - University of São Paulo Bauru - SP - Brazil.

Ana Paula Ribeiro do Vale PEDREIRA DDS - MS - Department of Dentistry - Faculty of Health Sciences University of Brasilia - Brasília - DF - Brazil

Adriana Pigozzo MANSO

DDS - MS - PhD - Department of Oral Biological \& Medical Sciences Division of Biomaterials - University of British Columbia Vancouver - Canada

Linda WANG DDS - MS - PhD - Department of Operative Dentistry - Endodontics and Dental Materials - Bauru School of Dentistry - University of São Paulo Bauru - SP - Brazil.

\begin{abstract}
Water contributes to the setting reaction of self-adhesive luting cements, however, it can also accelerate their degradation. Objectives: The aim of this study was to compare a self-adhesive resin luting cement to other resin-based and glass-ionomer luting materials with regards to water sorption (WS) and solubility (WSB). The tested null hypothesis was that there is no difference in respect to these properties among the materials. Material and methods: Eight specimens from each group (15 $\mathrm{mm}$ x 0.5 $\mathrm{mm}$ ) were prepared from self-adhesive luting cements Biscem (BC) and RelyX Unicem (R), dual-cure cements Bifix (BF), Allcem (A) and Enforce (E), chemical-cure cements C\&B (CB) and Cement Post (CP) and a glass-ionomer luting cement Meron $\mathrm{C}(\mathrm{M})$ as the control group. The dual-cure products were light-cured beneath an IPS Empress Esthetic ceramic disk (20 $\mathrm{mm} \times 1.5 \mathrm{~mm})$ and for the chemical reaction materials, a 15 min-interval was respected for removal from the mould. The WS and WSB were respectively calculated as $\left(\mathrm{m}_{2}-\mathrm{m}_{3} / \mathrm{V}\right)$ and $\left(\mathrm{m}_{1}-\mathrm{m}_{3} / \mathrm{V}\right)$. Mass values of $\mathrm{m} 1, \mathrm{~m} 2$ and $\mathrm{m} 3$ were determined by cycles of desiccation, water-immersion and a new desiccation. For each property, the data was analyzed by one-criteria ANOVA and Tukey tests $(\mathrm{p}<0.05)$. Results: The glass-ionomer cement presented the highest WS, followed by the selfadhesive luting cements. Other resin cements were less susceptible to WS. No materials differed from each other when the WSB was considered, except for the M, which presented the lowest WSB. Conclusions: Selfadhesive luting cements were more prone to WS since water is essential to their setting reaction. However, their WSB was similar to the other resinbased cements.
\end{abstract}

\section{KEYWORDS}

Glass-ionomer luting cement; Resin cements; Self-adhesive luting cements; Solubility; Water sorption.

\section{Resumo}

A água contribui para a reação de presa dos cimentos auto adesivos, entretanto pode acelerar a sua degradação. Objetivos: O objetivo deste estudo foi comparar cimentos auto adesivos a outros cimentos resinosos e material ionomérico em relação à sorção de água (WS) e solubilidade (WSB). A hipótese nula foi de que não há diferença em relação a essas propriedades entre os materiais. Material e métodos: Oito espécimes de cada grupo $(15 \mathrm{~mm} \times 0,5 \mathrm{~mm})$ foram preparados dos cimentos auto adesivos Biscem (BC) e RelyX Unicem (R), cimentos duais Bifix (BF), Allcem (A) e Enforce (E), cimentos químicos $\mathrm{C} \& \mathrm{~B}$ (CB) e Cement Post (CP) e um cimento ionomérico Meron C (M) como grupo controle. Os produtos duais foram fotoativados sob um disco cerâmico de IPS Empress Esthetic (20 mm x 1,5 mm) e para os materiais de reação química, um intervalo de $15 \mathrm{~min}$ foi respeitado para a remoção do molde. A WS e WSB foram respectivamente calculadas como $\left(m_{2}-m_{3} / V\right)$ e $\left(m_{1}-m_{3} / V\right)$. Valores de massa $m 1, m 2$ and m3 foram determinadas pelos ciclos de dessecação, imersão em água e nova dessecação. Para cada propriedade, os dados foram analisados pelos testes de ANOVA a um critério e Tukey $(\mathrm{p}<0.05)$. Resultados: $\mathrm{O}$ cimento ionomérico apresentou a maior WS, seguido dos cimentos auto adesivos. Os demais cimentos resinosos foram menos suscetíveis a WS. Nenhum material diferiu do outro quanto a WSB foi considerada, exceto por M, que apresentou a menor WSB. Conclusões: Cimentos auto adesivos foram mais suscetíveis a WS, uma vez que a água é essencial para sua reação de presa. Entretanto, seu WSB foi similar aos demais cimentos resinosos.

\section{Palavras-chave}

Cimento de ionômero de vidro; Cimento resinoso; Cimento auto adesivo; Solubilidade; Sorção de água. 


\section{INTRODUCTION}

A remarkable trend to simplify dental materials is observed in bonding restorative dentistry, which in fact, is greatly represented by simplified dentin bonding systems [1-3].

Many investigations are proposed to analyze their performance, which implies in reduced clinical steps but do not properly represent the best results $[2,4]$. These products are based on a concept of modification of tooth structures with their acidic content, expecting less sensitive techniques than total etching systems [5]. In the same direction, resin cements have been following the same modifications and a new category of self-etching adhesive resin cements was made available. According to the manufacturers, these materials do not require pretreatment of the tooth and are simple to use [6].

In order to clarify the applicability of these materials, different comparisons of distinct properties are necessary to avoid complications on the selection of a luting cement for clinical service [5-7].

The resin-based luting cements provide high bond strength to the materials and to hard dental tissues, less solubility, great stability and bio-compatibility [8]. However, since the oral environment consists of saliva with organic and inorganic substances, it likely accelerates the degradation over time [9].

Especially in this moist environment, the hydrophilic nature of the polymers determines the level of capacity to absorb water [10]. This feature is due to the chemical constitution of monomers with carbon and oxygen backbones, associated to hydrolytically susceptible ester groups [4].

Moisture diffuses into the polymers at different degrees, depending on a number of molecular and microstructural arrangements, mainly polarity of the molecular structure, presence of chemical groups capable of forming hydrogen bonds with water, degree of crosslinking, presence of residual monomers and/or other water-attracting species, i.e glass surfaces and crystallinity of the polymer (well-defined crystallites are inaccessible to water). As a result among these factors, the mechanism of water diffusion can be summarized in two main theories: (1) the free volume theory, according to which water diffuses through voids within the polymer and (2) the interaction theory, according to which water binds to specific ionic groups of the polymer chain. In this case, water diffusion occurs according to the water-affinity of these groups $[2,4,9,11]$.

It is expected that the absorption of water into polymer materials allow a volume expansion that potentially compensates for the initial setting shrinkage and, consequently, decreases the interfacial gap width and the resultant microleakage $[12,13]$.

On the other hand, excessive moisture can adversely affect the hybrid layer durability due to the degradation of either collagen fibrils or resin material [2,14-18].

It is known that the conversion of monomers into a polymer network is never complete for resinbased materials [11]. Clinically, as these materials are frequently light-activated through surfaces such as the dental structure or restorative materials, they act attenuating the necessary energy to polymerize them. As a result, a trend is observed that deteriorates the adhesive interface and decreases the mechanical properties. Significant amounts of unreacted monomers and other additives could be released, compromising the bio-compatibility of the dental restoration products [18-22]. These molecules are potentially hazardous to the pulp tissue [20,21].

Regarding the considerations mentioned above, the predictability in the long term of a resin based luting cement is strongly related to its susceptibility to water sorption and solubility [19]. Since the acid content of self-etching adhesive luting is significant, this property attributed to simplified dentin bonding systems can exacerbate their hydrophilic potential. Moreover, it is expected that water plays an important role in the setting reaction as it occurs to glass-ionomer based materials, which would justify its need.

Thus, this study aimed to compare a selfadhesive resin luting cement to other resin-based and glass-ionomer luting materials regarding water sorption and solubility. The tested null hypothesis was that there is no difference in respect to these properties among the materials.

\section{Methods and Materials}

This in vitro experimental design involved one factor (luting cement) in eight levels. The tested materials are presented in Table 1 . 


\section{Table 1 - Characteristics of luting materials under inVestigation}

\begin{tabular}{|c|c|c|c|}
\hline Category & Materials & Manufacturer & Composition \\
\hline \multirow[t]{2}{*}{$\begin{array}{l}\text { Self-adhesive luting } \\
\text { cements }\end{array}$} & $\begin{array}{l}\text { Rely X } \\
\text { Unicem }\end{array}$ & 3M ESPE, St Paul, MN, USA & $\begin{array}{l}\text { Powder: Glass particles, initiators, silica, substituted pyrimidine, calcium } \\
\text { hydroxide, peroxide composite and pigment. } \\
\text { Liquid: Methacrylate phosphoric acid ester, dimethacrylate, acetate, stabilizer } \\
\text { and initiator. }\end{array}$ \\
\hline & Biscem & $\begin{array}{l}\text { Bisco Inc., Schaumburg, IL, } \\
\text { USA }\end{array}$ & $\begin{array}{l}\text { Base: BisGMA, TEGDMA, EDMAB, dihydroxyethyl-p-toluidine, CQ, MEHQ, } \\
\text { BHT, dental glass, silica. } \\
\text { Catalyst: Bis (Hydroxyethyl Methacrylate) dhosphate, TEGDMA, benzoyl } \\
\text { peroxide, BHT, dental glass, silica. }\end{array}$ \\
\hline \multirow[t]{3}{*}{$\begin{array}{l}\text { Dual- cure resin } \\
\text { cements }\end{array}$} & Allcem & FGM, Joinville, SC, Brazil & $\begin{array}{l}\text { Methacrylic monomers, such as TEGDMA and Bis-EMA, inorganic load, photo- } \\
\text { initiator, co-initiator, catalysts, and pigments. }\end{array}$ \\
\hline & Enforce & $\begin{array}{l}\text { Denstply, Rio de Janeiro, RJ, } \\
\text { Brazil }\end{array}$ & $\begin{array}{l}\text { Base: TEGDMA, BDMA, boron aluminium glass silicate, pyrolytic silanized } \\
\text { silica, canforoquinone, EDAB, BHT, mineral pigments, DHEPT. } \\
\text { Catalyst: Titanium Dioxide, pyrolytic silanized sílica, mineral pigments, Bis- } \\
\text { GMa, EDAB, BHT, TEGDMA, Benzoyl Peroxide. }\end{array}$ \\
\hline & Bifix & $\begin{array}{l}\text { Voco, Cuxhaven, } \\
\text { Germany }\end{array}$ & Composition information was not supplied by manufacturer. \\
\hline \multirow[t]{2}{*}{ Chemical- cure } & $C \& B$ & $\begin{array}{l}\text { Bisco Inc., Schaumburg, IL, } \\
\text { USA }\end{array}$ & $\begin{array}{l}\text { Base: BisGMA, Ethoxylated Bisphenol "A" Dimethacrylate, TEGDMA, } \\
\text { dihydroxyethyl-p-toluidine, MEHQ, dental glass, silica, sodium fluroride, } \\
\text { pigments. } \\
\text { Catalyst: BisGMA, TEGDMA, benzoyl peroxide, BHT, silica. }\end{array}$ \\
\hline & $\begin{array}{l}\text { C e m e n t } \\
\text { Post }\end{array}$ & Angelus, Londrina, PR, Brazil & $\begin{array}{l}\text { Base: Barium Glass Ceramic, silica pyrogenic Bis-GMA, TEDMA, BHT, catalysts, } \\
\text { pigments. } \\
\text { Catalyst: Barium glass ceramic, pyrogenic silica, Bis-GMA, TEDMA, benzoyl } \\
\text { peroxide, stabilizer. }\end{array}$ \\
\hline Glass-inomer cement & Meron C & $\begin{array}{l}\text { Voco, Cuxhaven, } \\
\text { Germany }\end{array}$ & $\begin{array}{l}\text { Powder: Poly-acrylic acid, inorganic filler, pigments. } \\
\text { Liquid: water, tartaric acid, paraben. }\end{array}$ \\
\hline
\end{tabular}

HEMA - 2-hidroxyethyl methacrylate, BisGMA - bisphenol A diglycidyl methacrylate, CQ - camphoroquinone, TEGDMA triethylenoglycol dimethacrylate, UDMA - urethane dimethacrylate, EDAB - etyl4-dimethylamino benzoate, BHT - butyl hydroxytoluene, MEHQ - 4-Methoxy Phenol, EDMAB - ethyl N,N-dimethyl-4-aminobenzoate, BDMA - benzyldimethylamine, DHEPT- 2-hydroxyl-ptoluidine.

A clearer shade of each material was selected for this study, which does not necessarily mean the same as each manufacturer determines it. This study was performed in compliance with ISO 4049:1988 standard specifications [22], except for the photopolymerization, as will be described.

For each material, eight specimens $(15 \mathrm{~mm} \times 0.5$ $\mathrm{mm}$ ) were prepared, which were directly dispensed into a stainless steel matrix until filled completely, and some excess was extruded. Air bubbles were eliminated and a polyester strip was placed over the luting cement and covered with a glass slide. The dual cure products were light-cured beneath an IPS Empress Esthetic (Ivoclar-Vivadent, Schaan, Liechtenstein) ceramic disk (20 $\mathrm{mm} \times 1.5 \mathrm{~mm})$ and for the chemical cure materials, a 15 min-interval was allowed before its removal from the mold. The polymerized specimens were removed from the matrix and the excesses were eliminated with a scalpel blade.

The specimens were stored in desiccators at $37{ }^{\circ} \mathrm{C}$ 
containing silica gel. The discs were weighed daily in an analytical balance (Tel Marke; Bel Quimis, São Paulo, SP, Brazil) accurate to $0.01 \mathrm{mg}$, constituting a weighing cycle every $24 \mathrm{~h}$. The complete cycle was repeated until a constant mass (m1) was obtained, i.e., until the mass loss of each specimen was not more than $0.2 \mathrm{mg}$ per $24 \mathrm{~h}$ cycle.

Thereafter, the specimens were individually stored in a volume of water for immersion, at least $6 \mathrm{~mL}$ at $37^{\circ} \mathrm{C}$ for 7 days. The specimens were weighed again daily after being carefully wiped with absorbent paper (Gala ${ }^{\circledR}$, Bragança Paulista, SP, Brazil). When the constant weight was obtained, this value was recorded as $\mathrm{m} 2$. After this weighing, the specimens were returned to the first desiccator and the entire mass re-conditioning cycle was repeated and the constant mass was recorded as $\mathrm{m} 3$.

The thickness of each specimen was measured at three different points using a digital electronic caliper (Mitutoyo Corporation, Tokyo, Japan). The values for water sorption and solubility, in micrograms per cubic millimeter, were calculated using the following equations:

$$
\begin{gathered}
\mathrm{WS}=\left(\mathrm{m}_{2}-\mathrm{m}_{3}\right) / \mathrm{V} \\
\mathrm{WSB}=\left(\mathrm{m}_{1}-\mathrm{m}_{3}\right) / \mathrm{V}
\end{gathered}
$$

The assumptions of equality of variances and normal distribution of errors were checked for the tested response variables. Since the assumptions were satisfied, the data was submitted to one-way ANOVA and Tukey post hoc testing $(\mathrm{p}<0.05)$.

\section{RESULtS}

Water sorption and solubility values (in $\mu \mathrm{g} / \mathrm{mm} 3$ ) are summarized in tables 2 and 3, respectively.

\section{Table 2 - Mean and (standard deviations) OF WATER SORPTION AMONG TESTED LUTING CEMENTS IN MG/MM3}

\begin{tabular}{llll}
\hline MATERIALS & MEAN & SD & TuKEY TEST $^{\star}$ \\
\hline M & 200.7 & 16.89 & $\mathrm{~A}$ \\
$\mathrm{BC}$ & 75.84 & 7.08 & $\mathrm{~B}$ \\
$\mathrm{R}$ & 51.43 & 7.27 & $\mathrm{BC}$ \\
$\mathrm{CB}$ & 23.63 & 3.50 & $\mathrm{CD}$ \\
$\mathrm{BF}$ & 20.00 & 2.35 & $\mathrm{CD}$ \\
$\mathrm{CP}$ & 19.33 & 1.84 & $\mathrm{CD}$ \\
$\mathrm{E}$ & 18.08 & 1.90 & $\mathrm{D}$ \\
$\mathrm{A}$ & 15.19 & 1.66 & $\mathrm{D}$ \\
\hline
\end{tabular}

$\mathrm{N}=8 ;{ }^{*}$ Different uppercase letter denotes statistical differences among materials
Table 3 - Mean and (standard deviations) of WATER SOLUBILITY AMONG TESTED LUTING CEMENTS IN MG/MM3

\begin{tabular}{l|l|l|l}
\hline MATERIALS & MEAN & SD & TUKEY $^{*}$ \\
\hline $\mathrm{R}$ & 14.12 & 2.19 & $\mathrm{~A}$ \\
\hline $\mathrm{CB}$ & 9.45 & 2.89 & $\mathrm{~A}$ \\
\hline $\mathrm{E}$ & 6.56 & 1.73 & $\mathrm{~A}$ \\
\hline $\mathrm{BC}$ & 6.50 & 1.20 & $\mathrm{~A}$ \\
\hline $\mathrm{CP}$ & 4.05 & 1.24 & $\mathrm{~A}$ \\
\hline $\mathrm{BF}$ & 1.86 & 0.80 & $\mathrm{~A}$ \\
\hline $\mathrm{A}$ & -0.15 & 1.10 & $\mathrm{~A}$ \\
\hline $\mathrm{M}$ & -80.45 & 14.21 & $\mathrm{~B}$ \\
\hline
\end{tabular}

$\mathrm{N}=8$; ${ }^{\star}$ Different uppercase letter denotes statistical differences among materials

The highest WS was observed for the $\mathrm{M}$ and the lowest for the A, as showed in Table 2. The M material was statistically different than all the tested materials $(p<0.05)$. The self-etching luting cement $\mathrm{BC}$ showed the second highest mean values of WS, with no differences when compared to the R, which was the third most susceptible to WS. The R material was not statistically different than the $\mathrm{CB}, \mathrm{BF}$ and $\mathrm{CP}$. Self-adhesive luting cement $\mathrm{BC}$ was statistically more prone to WS when compared to the dual cure cements $\mathrm{BF}, \mathrm{A}, \mathrm{E}$, and to the chemical cure cements $\mathrm{CB}$ and CP.

When compared to the glass-ionomer luting cement, the self-adhesive materials demonstrated higher WS.

According to the values of WSB, M showed the lowest means, which was statistically different than all the other tested materials ( $p<0.05)$, as shown in table 3 .

\section{Discussion}

Since polymerization of light-cured or dual-cured luting cements commonly implies in an interposition of the tooth structure or the restoration material between the cement and the light-activation unit tip, this study was conducted using an usual ceramic material disk in order to reproduce a clinical situation $[23,24]$.

In spite of the features regarding curing, [25] it is important to consider the composition of the materials in their own performance [10,26,27]. Water- sorption is strongly associated to an organic matrix polymeric nature. The curing process can interfere in their polymeric arrangement since more cross-link and 
conversion degree allows less water sorption $[2,4]$. In general, dual cure and chemical cements performed in a similar profile with regards to WS. The results of this study suggest that the polymerization process was not the main cause of the WS profile of these materials.

A great number of investigations demonstrated the influence of monomer constitutions such as BisGMA, TEGDMA and UDMA as they commonly are present in resin-based materials. Many investigations reported minor sorption in the BisGMA, while TEGDMA was more susceptible to be released $[25,26]$.

The incorporation of water into polymer structure chains in a moist environment also occurs; by means of the free or interaction process $[2,4]$. Hydrophilic and acidic components exacerbate this affinity in water. In the Malacarne et al. [4] investigations, it is related that the sorption of water by free incorporation occurred to all the tested monomers including BisGMA. However, water incorporation due to the interaction theory was attributed to more hydrophilic monomers as HEMA was presented.

Based on these previous reports, we are encouraged to state that the sorption of water presented by the tested self-adhesive luting cements is strongly related to their acidity and hydrophilic features since their characteristics are necessary to establish the self-etching process [25]. More complex monomer combinations as presented in self-etching cements clearly highlight their susceptibility to water sorption.

Resin-based materials are based on phosphates and meth-acrylate groups, which are susceptible to water sorption [28]. The hydrophilicity of these monomers permits water absorption even after curing $[4,17,29,30]$, which represents a weak property with undesirable clinical consequences. Carvalho et al. [31] also claims the formation of water blisters in the self-adhesive luting cement layers.

According to Mortier et al. [9], when equal volumes of materials are compared, a greater amount of particles reduces the organic matrix volume, and consequently leads to less water sorption. Unfortunately, although all the tested luting cements presented particles, there is a lack of information about their size and amount, which can determine their different performances.

In the present study, the glass-ionomer luting cement, Meron, presented a remarkable water sorption, which is in accordance to a previous performance as reported by Knobloch et al. [32] and Gerdolle et al. [33]. Due to the hydrogel formation of glass-ionomer materials, they strongly absorb a greater amount of water compared to resin-based materials [18].
Water sorption is a continuous process as previously stated by Chutinan et al. [18] and Huang et al. [29], which verified an increase of volume of materials submitted to a water sorption test after 56 days. Archegas et al. [34] related greater water sorption when prolonged storage occurs.

The other relevant property analyzed in the present study is related to the solubility of materials in water storage. Leachability of components into the dentinal tubules can provoke inflammation in the dentin pulp complex [20] and bonding interface degradation $[4,35]$.

Only the glass-ionomer luting cement was statistically different from the other tested materials. Glass-ionomer cements allow fluoride lixivia and so solubility is an inherent property of this material category $[9,36]$. The lower the $\mathrm{pH}$ level of the environment, the more fluoride leaching occurs [35].

Negative values of solubility of glass-ionomer cements point out the high capability of water absorption and adsorption, masking its solubility $[4,9]$. It was previously demonstrated that Meron $\mathrm{C}$, as a glass-ionomer cement, contains water in its composition and consequently the desiccation method applied in this study might not actually represent glass-ionomer sorption and solubility $[18,33]$.

There were no differences among all the resin-based materials. In the RelyX Unicem reaction, fluoride release is expected, however, it did not support any difference in the Biscem, which did not present fluoride in its composition [37]. Costa et al. [21] verified that RelyX Unicem didn't release particles into the dentin, suggesting low solubility. Additionally, since it didn't constituted tags formation, it might not influence a release into the dentinal tubules.

A material that greatly absorbs water does not exactly present high solubility and vice versa. In the present study, the Biscem was more prone to sorption compared to the Rely X Unicem, but the opposite was verified related to solubility even no significant difference was detected. Malacarne et al. [4] reported similar results, since they showed that less hydrophilic resin presented higher solubility compared to more hydrophilic resin.

Self-adhesive luting cements can be attributed to glass-ionomer materials, considering its ability to adhere to tooth structures and due to its acidic composition and calcium content. However, the results of the present study can support values more similar to resin-based materials compared to glassionomer cements.

Even though the water sorption of the self- 
adhesive materials was greater than the other resinbased materials, it was significantly lower than the glass-ionomer cement. This information is essential to highlight these materials as a particular category and does not erroneously anticipate one to indicate it as a glass-ionomer cement. Although materials prone to water sorption represent a critical point to facilitate degradation, other authors were encouraged to attest that it does not necessarily indicate more clinical fragility, since it is represented by the glass-ionomer cement's clinical performance $[38,39]$. In a clinical point of view, a moist environment is the actual oral situation and thus, resin-based materials will be susceptible not only to their own hydrolysis but also to the hybrid layer and collagen fibrils degradation over time [2,29]. Studies such as Viotti et al. [3] recently showed that most self-adhesive luting agents provided low bond strength values on the dentin surfaces, which indicate the need of interaction of the analysis of different properties of these materials to correctly indicate their use or not.

The overall findings apparently suggest that the solubility of self-etching luting cements does not seem to be more hazardous, as indicated, to other resinbased materials. The great water sorption suffered by the tested self-etching luting cements indicates the need for further investigations to verify whether their acidic monomers hydrolytic stability is sufficient, mainly under critical clinical situations. Even though it is high, a previous study demonstrated more stability over time compared to other resin-based cements [8].

\section{Conclusion}

Self-adhesive luting cements perform differently than resin-based available cements, and are more prone to water sorption. Conversely, they did not inhibit more aggressiveness comparatively to resinbased materials by means of solubility.

\section{Acknowledgements}

The authors would like to acknowledge Laboratório Romanini, Bisco, 3M ESPE, VOCO, Dentsply, Angelus and FGM for supplying the materials and FUNADESP for supplying fellowship supply.

\section{References}

1. Tay FR, King NM, Chan KM, Pashley DH. How can nano-leakage occur in self-etching adhesive systems that demineralize and infiltrate simultaneously? J Adhes Dent. 2002;4(4):255-69.

2. Fabre HSC, Fabre S, Cefaly DFG, Carrilho MRO, Garcia FCP, Wang L. Water sorption and solubility of dentin bonding agents light-cured with different light sources. J Dent. 2007;35(3):253-8.

3. Viotti RG, Kasaz A, Pena CE, Alexandre RS, Arrais CA, Reis AF. Micro-tensile bond strength of new self-adhesive luting agents and conventional multi-step systems. J Prosthet Dent. 2009;102(5):306-12.

4. Malacarne J, Carvalho RM, Goes MF, Svizero N, Pashley $\mathrm{DH}$, Tay FR, et al. Water sorption/solubility of dental adhesive resins. Dent Mater. 2006;22(10):973-80.

5. Escribano N, Macorra JC. Micro-tensile bond strength of self-adhesive luting cements to ceramic. J Adhes Dent. 2007;8(5):337-41.

6. Pegoraro TA, Silva NRFA, Carvalho RM. Cements for use in esthetic dentistry. Dent Clin North Amer. 2007;51(2):45371.

7. Al-Assaf K, Chakmakchi M, Palaghias G, KaranikaKouma A, Eliades G. Interfacial characteristics of adhesive luting resins and composites with dentine. Dent Mater. 2007;23(7):829-39.

8. Pedreira APRV, Pegoraro LF, Góes MF, Pegoraro TA, Carvalho RM. Micro-hardness of resin cements in the intraradicular environment: Effects of water storage and

softening treatment. Dent Mater. 2009;25(7):868-76.

9. Mortier E, Gerdolle DA, Jacquot B, Panighi MM. Importance of water sorption and solubility studies for couple bonding agent-resin-based filling material. Oper Dent. 2004;29(6):669-76.

10. Asmussen E, Peutzfeldt A. Influence of UEDMA, BisGMA and TEGDMA on selected mechanical properties of experimental resin composites. Dent Mater. 1998;14(1):516.

11. Svizero NR, Alonso RCB, Wang L, Palma-Dibb RG, D'Alpino PHP. Kinetic of water diffusion and color stability of a composite resin as a function of the curing tip distance. Mater Res. 2012;15(4):603-10.

12. Torstenson B, Brännström $\mathrm{M}$. Contraction gap under composite resin restorations: effect of hygroscopic expansion and thermal stress. Oper Dent. 1988;13(1):2431.

13. Feilzer AJ, de Gee AJ, Davidson CL. Relaxation of polymerization contraction shear stress by hygroscopic expansion. J Dent Res. 1990;69(1):36-9.

14. Mazzitelli C, Monticelli F, Osorio R, Casucci A, Toledano M, Ferrari M. Effect of simulated pulpal pressure on self-adhesive cements bonding to dentin. Dent Mater. 2008;24(9):1156-63.

15. Tay FR, Frankenberger R, Krejci I, Bouillaguet S, Pashley DH, Carvalho RM. Single-bottle adhesives behave as permeable membranes after polymerization. I. In vivo evidence. J Dent. 2004;32(8):611-21.

16. Bonfante EA, Pegoraro LF, Góes MF, Carvalho RM. SEM observation of the bond integrity of fiber-reinforced 
composite posts cemented into root canals. Dent Mater. 2008;24(4):483-91.

17. De Munck J, Van Landuyt K, Peumans M, Poitevi A, Lambrechts P, Braem M. A critical review of the durability of adhesion to tooth tissue: methods and results. J Dent Res. 2005;84(2):118-32.

18. Chutinan S, Platt JA, Cochran MA, Moore BK. Volumetric dimensional change of six direct core materials. Dent Mater. 2004;20(4):345-51.

19. Geurtsen W. Substances released from dental resin composites and glass ionomer cements. Eur J Oral Sci. 1998;106(2 Pt 2):687-95.

20. Hofmann N, Renner J, Hugo B, Klaiber B. Elution of leachable components from resin composites after plasma arc vs. standard or soft-start halogen light irradiation. J Dent. 2002;30(5-6):223-32.

21. Costa CAS, Hebling J, Randall RC. Human Pulp Response To Resin Cement Used To Bond Inlay Restorations. Dent Mater. 2006;22(10):954-62.

22. International Organization for Standardization. ISO 4049: Dentistry: resin-based filling materials. Geneve; 1988.

23. El-Mowafy OM, Rubo MH. Influence of composite inlay/ onlay thickness on hardening of dual-cured resin cements. J Can Dent Ass. 2000;66(3):147.

24. Piva E, Correr-Sobrinho L, Sinhoreti MAC, Consani S, Demarco F, Powers JM. Influence of energy density of different light sources on knoop hardness of a dual-cured resin cement. J Appl Oral Sci. 2008;16(3):189-93.

25. Nalçaci A, Ulusoy N, Atakol O. Time-based elution of TEGDMA and BisGMA from composite resin cured with LED, QTH and High-intensity QTH lights. Oper Dent. 2006;31(2):197-203.

26. Asmussen E, Peutzfeldt A. Influence of selected components on crosslink density in polymer structures. Eur J Oral Sci. 2001;109(4):282-5.

27. Guo X, Wang Y, Spencer P, Ye Q, Yao X. Effects of water content and initiator composition on photo-polymerization of a model BisGMA/HEMA resin. Dent Mater. 2008;24(6):824-31.

28. Ogliari FA, Silva EO, Lima GS, Madruga FC, Henn S, Bueno M. Synthesis of phosphate and bonding to dentin: Esterfication methods and use of phosphorus pentoxide. J Dent. 2008;36(3):171-7.

29. Huang C, Kei L, Wei SHY, Cheung GSP, Tay FR, Pashley $\mathrm{DH}$. The influence of hygroscopic expansion of resin-based restorative materials on artificial gap reduction. J Adhes Dent. 2002;4(1):61-71.

30. Fabianelli A, Goracci C, Bertelli E, Monticelli F, Grandn MF. In vitro evaluation of Wall-to-Wall adaptation of a self-adhesive resin cement used for luting gold and ceramic inlays. J Adhes Dent. 2005;7(1):33-40.

31. Carvalho RM, Pegoraro TA, Tay FR, Pegoraro LF, Silva NRFA, Pashley DH. Adhesive permeability affects coupling of resin cements that utilize self-etching primers to dentine. J Dent. 2004;32(1):55-65.

32. Knobloch LA, Kerby RE, Mcmillen K, Clelland N. Solubility and sorption of resin-based luting cements. Oper Dent. 2000;25(5):434-40.

33. Gerdole DA, Mortier E, Jacquot B, Panighi MM. Water sorption and water solubility of current luting cements: An in vitro study. Quintessence Int. 2008;39(3):107-14.

34. Archegas LRP, Caldas DBM, Rached RN, Viera S, Souza EM. Sorption and solubility of composites cured with quartz-tungsten halogen and light emitting diode lightcuring units. J Contemp Dent Pract. 2008;9(2):73-80.

35. Armstrong SR, Vargas MA, Chung I, Pashley DH, Campbell JA, Laffoon JE. Resin-dentin interfacial ultrastructure and micro-tensile dentin bond strength after five-year water storage. Oper Dent. 2004;29(6):705-12.

36. Ariffin Z, Ngo H, Mcintyre J. Enhancement of fluoride release from glass ionomer cement following a coating of silver fluoride. Aus Dent J 2006;51(4):328-32.

37. Gerth HUV, Dammaschke T, Züchner H, Schäfer E. Chemical analysis and bonding reaction of RelyX Unicem and Bifix composites- a comparative study. Dent Mater. 2006;22(10):934-41.

38. Behr M, Rosentritt M, Loher H, Kolbeck C, Trempler C, Stemplinger B. Changes of cement properties by mixing errors: The therapeutic range of different cement types. Dent Mater. 2008;24(9):1187-93.

39. Heintze SD, Cavalleri A, Zellweger G, Büchler A, Zappini G. Fracture frequency of all-ceramic crowns during dynamic loading in a chewing simulator using different loading and luting protocols. Dent Mater. 2008;24(10):1352-61.

Received:2012-Oct.-28

Accepted: 2013-Mar.-01

\section{Corresponding author}

Prof. Dr. Linda Wang

Department of Operative Dentistry, Endodontics and Dental Materials

Bauru School of Dentistry, University of São Paulo Alameda Octávio Pinheiro Brisolla, 9-75 Phone: 55-14-3235-8480/ fax: 55-14-3235-8523 e-mail: wang.linda@usp.br 